\title{
The Quality Life of Matriarch and Program of Poverty Reduction in Jember Regency
}

\author{
Ade Ananta Pratiwi ${ }^{1 \text { (corresponding author) }}$ Al Munawir $^{2}$, Dewi Rokhmah ${ }^{3}$ \\ ${ }^{1}$ Postgraduate Program of Public Health Science, Universitas Jember, Indonesia; \\ ananta.pratiwi10@gmail.com \\ ${ }^{2}$ Faculty of Medicine, Universitas Jember; Indonesia \\ ${ }^{3}$ Faculty of Public Health, Universitas Jember, Indonesia
}

Submitted: December 28, 2019 -Revised: January 18, 2020 -Accepted: January 26, 2020 -Published: January 31, 2020

\begin{abstract}
Introduction: Poverty was regarded as a common problem existed in many countries, either in developed countries or developing countries, even, the poverty was still a priority problem in SDGs era. In 2018 East Java was positioned on the first rank of highest level of poverty in Java, particularly Jember Regency was ranked in the second. The government of East Java has observed this poverty phenomenon on female society, which was then called as poverty feminization. Therefore, the government of East Java established a program of poverty alleviation on women, it was known as a feminization program of poverty reduction. This program aimed to provide job or job, so the matriarch would have access to several sectors, as economic, education, or health. The easy access given to the matriarch was expected to realize more quality of life. Methods: This research was categorized into quantitative research and exerted cross sectional approach. The total population in this research was taken from all women who got help from the feminization program of poverty reduction in Jember, specifically the total were about 1227 respondents. The method of sampling was purposive sampling by employing representative of data sampling in each sub-regency. The total sample in this research were 302 respondents. Further, the data was collected through instrument of WHOQOL-BREF questionnaire, while the data was analyzed through Spearman correlation method. Results: According to the result of data analysis on factor of job to the life quality, it was obtained p-value of 0.000 , which referred the correlation between job and life quality of matriarch. Moreover, the data analysis on factor of income to the life quality, it was obtained pvalue of 0.000 , which referred the relation between income and life quality of matriarch. Conclusion: There was a relation between job as well as income and the life quality of matriarch.
\end{abstract}

Keywords: matriarch; feminization of poverty; job; income; life quality

\section{INTRODUCTION}

\section{Background}

The issue of poverty becomes a prolonged problem until nowadays ${ }^{(1)}$. The poverty is one of problems that exists in many countries, either in developed countries or developing countries. The level of poverty in America in last 2018 was recorded as bigger on woman society, in approximately $12.9 \%$, while on the man, the level of poverty was in approximately $10.6 \%{ }^{(2)}$.

The total of poor society in Indonesia in last 2018 was 25.95 million people, this result was reduced than the total in 2017. East Java was positioned on the first rank in Java Island where the total of poor population was about 4,332,590 people and income average per capita per month IDR 573,574 (Central Bureau of Statistics, 2018). Moreover, Jember Regency was ranked o the second in East Java after Malang Regency where the total of poor population was about 243,420 people $^{(3)}$.

Based on the data which has been released by The National Team for the Acceleration of Poverty Reduction, overall, the population distribution where the matriarch did not finish Elementary School degree or had educational background of elementary school in approximately $91 \%$, while $9 \%$ were the matriarch who had finished their education in Junior High School. According to the analysis of work load, the poverty has caused the women bear heavier burden and responsibility than the men do. The government of East Java Province has a commitment to implement a prolonged development program which is focused on the society and emphasized on society participation, the economic growth is taken side on the poor population or society, and gender equality. The problem of poverty becomes a concern of East Java government, however, currently the government specifically examine the increase of women population who are living below the poverty line. Further, this phenomenon is called as a feminization of poverty which requires to special attempt and handling in order to improve economic status of society ${ }^{(4)}$. The spread of poverty is a core of whole development problems in a country ${ }^{(5)}$. 
Based on those backgrounds, the poverty and health issue on women are regarded an interesting issue which can be related to some indicators as SDGs, they are to end the poverty in all forms wherever, to end hunger and achieve to food security as well as better nutrition and support sustainable agriculture system, to ensure health life and support prosperity for all society in all ages, and to achieve gender equality and empower all women and girls.

The quality of life is an individual perception in his life which is considered from cultural contexts, as behavior and value system where the individual live and concern to the standard of life, expectation, enjoyment, and individual valuation on his position in life. According to WHO, the measurement of life quality covers to physical health, psychological health, freedom level, social relation, and environmental relation ${ }^{(6)}$.

Based on that background, the researchers were interested to examine the life quality of matriarch as an indicator to value the success of feminization program of poverty reduction.

\section{Goal}

This research aimed to examine the life quality of matriarch as an indicator of success on feminization program of poverty reduction in Jember Regency.

\section{METHODS}

This research was categorized into quantitative research and exerted cross sectional research approach. This research was conducted in Jember Regency, specifically in 16 Sub-regencys. Moreover, this research and data analysis was started along August 2019 to November 2019.

The research population was taken from all receivers of help or matriarch in Jember Regency in approximately 1227 people who were matched to the research criteria that have been determined by the Community and Village Empowerment Service of East Java which consisted of widow, abandoned by the husband, whose husband was in chronic pain, and non-marital single mother.

The method of sampling was Slovin formula and was then represented in each sub-regency through Lemeshow formula, it resulted to 302 respondents who were spread over 16 sub-regencys.

The research variables were consisted of independent variable, job and income and dependent variable, quality of life. The instrument of data collection in this research was WHOQOL-BREF questionnaire. Further, the result of data collection was then analyzed through spearman correlation method.

This research had been through ethical test in health research ethical commission of Dentistry Faculty of Universitas Jember with this following permission number 583/UN25.8/KEPK/DL/2019.

\section{RESULTS}

\section{Respondent Characteristics}

Table 1. Respondent characteristics

\begin{tabular}{|c|c|c|c|}
\hline No. & Matriarch status & Frequency & Percentage \\
\hline 1 & Died Husband & 228 & 75.50 \\
2 & Divorced & 59 & 19.50 \\
3 & Abandoned & 12 & 4.00 \\
4 & The husband suffered from chronic pain & 3 & 1.00 \\
5 & Non marital single mother & 0 & 0 \\
\hline Total & & 302 & 100 \\
\hline
\end{tabular}

The table 1 has explained the respondent characteristics based on the status of matriarch. The matriarch status was dominated by whose husband were died $75.5 \%$. Next, $19.5 \%$ were the matriarch who had been divorced, $4.0 \%$ were abandoned, and $1.0 \%$ were the matriarch whose husband suffered chronic pain for years.

\section{Job Status}

The table 2 has explained the respondent job which was divided into three categories, unemployed, temporary job, and employed. Most of respondents who have regular or permanent job $86.8 \%$, while $12.2 \%$ of 
respondents have temporary job or job, and $1 \%$ of respondents were unemployed. The aspect of job was expected to improve the respondent capability to fulfill the daily need.

Table 2. Job status of matriarch

\begin{tabular}{|c|c|c|c|}
\hline No. & Job Status & Frequency & Percentage \\
\hline 1 & Employed & 262 & 86.80 \\
2 & Temporary employed & 37 & 12.20 \\
3 & Unemployed & 3 & 1.00 \\
\hline Total & & 302 & 100 \\
\hline
\end{tabular}

Income

Table 3. Income of matriarch

\begin{tabular}{|c|c|c|c|}
\hline No. & Income & Frequency & Percentage \\
\hline 1 & >IDR 2,000,000 & 46 & 15.20 \\
2 & IDR 600,000 - IDR 2,000,000 & 132 & 43.70 \\
3 & <IDR 600,000 & 124 & 41.10 \\
\hline Total & & 302 & 100 \\
\hline
\end{tabular}

The table 3 has explained the earning income which was based on minimum wage of East Java Province. As many as $43.7 \%$ earned approximately IDR $600,000-2,000,000$ per month. Yet, there were a few of respondents earned income lesser than IDR 600,000 per month 41.1\%. This situation indicated that there were still respondents who were categorized into poor family category.

\section{Life Quality}

Table 4. Life quality of matriarch

\begin{tabular}{|c|c|c|c|}
\hline No. & Life quality & Frequency & Percentage \\
\hline 1 & Good & 160 & 53.00 \\
2 & Adequate & 119 & 39.40 \\
3 & Bad & 23 & 7.60 \\
\hline Total & & 302 & 100 \\
\hline
\end{tabular}

The table 4 has explained that the life quality of matriarch was divided into three categories: good, adequate, and bad category. As many $53 \%$ of respondents had a good quality of life, $39.4 \%$ had adequate quality of life, and $7.6 \%$ had bad quality of life.

\section{Result of Spearman Correlation Test}

Table 5. Result of Spearman correlation test

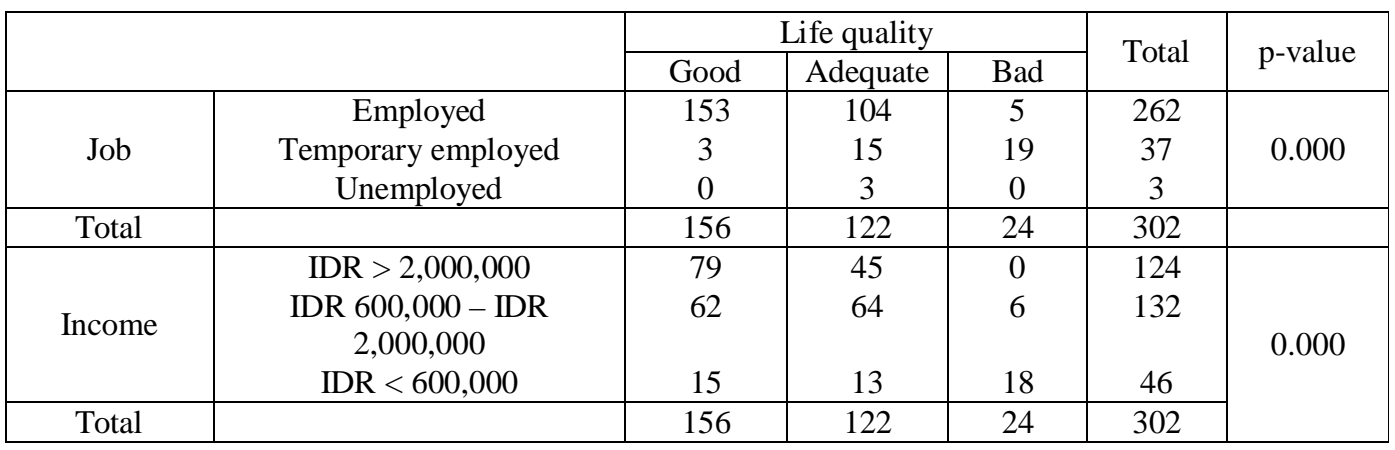


The table 5 has explained that the result of data analysis employed spearman by correlating job status and income to the life quality of matriarch. According to the result of data analysis on factor of job to the life quality, it was obtained $\mathrm{p}$ value $(0.000)<\alpha(0.05)$ which referred the relation between job and life quality of matriarch. Moreover, the data analysis on factor of income to the life quality, it was obtained p value $(0.000)<\alpha$ $(0.05)$ which referred the relation between income and life quality of matriarch.

\section{DISCUSSION}

\section{Job and Life Quality of Matriarch}

The research finding demonstrated the relation between job status and life quality of matriarch. The factor of job was a demographic factor which had significant effect to the life quality if it was compared to the other demographic factor ${ }^{(7)}$. Moreover, the job was referred as an activity where the individual spent time which was equal to the bedtime and other activities ${ }^{(8)}$.

The factor beyond disparity between men and women in unjob access was that the women have double burden which compelled them to accomplish home task as well as work out of home ${ }^{(9)}$.

The research done by Moons, et al have stated that the difference on life quality between the society in status of student, employed, job seeker, unemployed, and incapable of work because each had restriction on their $\mathrm{own}^{(10)}$. The job which encouraged individual to have quite intense interaction with the surrounding would affect the perspective on several kinds of problem, including to health factor. By having job, the physical mobility could be maintained and the stress level could be minimized.

The feminization program of poverty reduction was a program of empowerment on women, especially for them who were in matriarch status. The women who were stuck within poverty circle would experience many problems in either economic or health aspect, moreover, their status as head of household where they have and endure double responsibility, as the wage earner who could not leave their role as a mother in the family. The women who became matriarch must earn money for the family's need and ensure fulfilling the family's need. One of complicating factor within this situation was the low degree of education. Further, the education or several aspects within education as literacy, science, and mental development were parts of human life which became a consideration to value index of international development and life quality ${ }^{(11)}$.

The indicator of success on feminization program of poverty reduction consisted of right on target, right on amount and right on benefit. Based on the research finding, the researchers concluded that this program ran well since it was able to change the economic status of society, particularly the women who were in matriarch status. In addition, the change of economic status on matriarch delivered and affected to the health status of their family member, where the access of health could be reachable.

One significant aspect which supported the attempt of poverty alleviation was accurate data, where the data could be used by the government to take a decision. This data could be a comparison from year to year ahead ${ }^{(12)}$. The target of this program has been concerned to update of integrated data basis which was completed by double checking from the next cadre called as "Mother Care".

\section{Income and Life Quality of Matriarch}

The women in status of matriarch had greater risk to experience poverty which was caused by the social unluckiness or disadvantage ${ }^{(13)}$. The harder responsibility would exist when they must not only fulfilling their own need, but also need of their family members, including to their children ${ }^{(14)}$.

Based on the research findings, it showed the relation between factor of income and life quality of matriarch. Job was often related to the earning income, likewise the earning income was often related to the human need $^{(15)}$. The research done by Kusuma has revealed the relation between factor of income and life quality, where the individual with low income would have risk to undergo poor quality of life ${ }^{(16)}$.

This research finding demonstrated that some respondents had income lesser than IDR 600,000. This result referred that there were still some residents in Jember, especially women who were below the poverty limit. The aspect of poverty was a basic problem, since this aspect was related to the capability of basic need fulfillment ${ }^{(17)}$. Moreover, the low earning income would complicate the fulfillment of life need, including to economic, educational, and health aspect. The limitation within life need fulfillment would finally influence the quality of life.

Several attempts have been implemented by the government to overcome poverty issue and was applied into a form of policy and various kinds of program in either direct or indirect ${ }^{(18)}$. The success of program could be identified from change of economic aspect, the change from condition of unjob into job, increased income, and 
easy access in several sectors. In addition, this program was regarded as successful alleviating and reducing poverty level, since it was able to create job opportunity for all society, especially the matriarch.

The reduction of poverty level was an issue which has been a serious concern in SDGs era ${ }^{(19)}$. This program became a program which contributed in the attempt of poverty reduction in SDGs era. Moreover, the feminization program of poverty reduction has a correlation to several goals of SDGs, as to end all forms of poverty anywhere, end hunger, and guarantee gender equation as well as women empowerment.

\section{CONCLUSION}

Based on the research finding, the researchers concluded that the life quality of matriarch in Jember Regency was regarded as good where the majority of them were employed and earned income above the poverty line or standard. The feminization program of poverty reduction in Jember Regency was said as successful, since this program was able to provide job opportunities for the women who were especially in poverty circle, so they could rise improving their quality of life.

\section{REFERENCES}

1. Prawoto N. Understanding Poverty and its Prevention Strategies (Memahami Kemiskinan dan Strategi Penanggulangannya). Jurnal Ekonomi dan Studi Padjajaran. 2009;9(1): 56-68.

2. Semega J, Kollar M, Creamer J, Mohanty A. income and Proverty in the United States. U.S Government Printing Office: Washington DC; 2018.

3. BPS Provinsi Jawa Timur. Number and Percentage of Poor Population, P1, P2 and Poverty Line by Regency/City Year Jumlah dan Persentase Penduduk Miskin, P1, P2 dan Garis Kemiskinan menurut Kabupaten/Kota Tahun 2018 [Internet]. Badan Pusat Statistik Provinsi Jawa Timur. 2018 [cited 2019 Des 2]. Available from: http://jatim.bps.go.id/

4. DPMD. General Guidelines for JALIN MATRA Prevention of Feminization Poverty (Pedoman Umum Jalin Matra Penanggulangan Feminisasi Kemiskinan). Dinas Pemberdayaan Masyarakat dan Desa Provinsi Jawa Timur: Surabaya; 2017.

5. Todaro, Michael P, Smith SC. Economic Development. Pearson Ltd: New York; 2015.

6. WHO. 2004. Programme on Mental Health WHOQOL Measuring Quality of Life. World Health Organization: Geneva ; 2004.

7. Izawa N. (2004). An Exploration of Subjective Well Being: A Review of Empirical Factors and Paths for The Future. University of Hartford: USA ; 2004.

8. Junaidy D, Surjaningrum ER. Difference Quality of Life in Early Adults who Work and who do not Work (Perbedaan Kualitas Hidup pada Dewasa Awal yang Bekerja dan yang tidak Bekerja). Jurnal Psikologi Industri dan Organisasi. 2014;3(2): 102-107.

9. Noerdin E, Agustini E, Pakasi DT, Aripurnami S, Hodijah SN. Portrait of Women's Poverty (Potret Kemiskinan Perempuan).Women Research Institute: Jakarta; 2006.

10. Moons P, Marquet K, Budts W, Geest S. Validity, reliability and responsiveness of the "Schedule for the Evaluation of Individual Quality of Life - Direct Weighting" (SEIQoL-DW) in congenital heart disease. Health and Quality of Life Outcomes: Switzerland; 2004.

11. Hagherty MR, Vogel J, Micholas AC, Peterson M, Sharpe A, Sirgy J, Cummins R, Ferris AL, Land K. Quality of Life Indexes for National Policy: Review and Agenda for Research. Bulletin of Sociological Methodology: BMS; 2001.

12. Ferezagia DV. Poverty Rate Analysis in Indonesia (Analisis Tingkat Kemiskinan di Indonesia). Jurnal Sosial Humaniora Terapan. 2018; 8(3): 1-6.

13. Laksono P. Feminization of Poverty Qualitative Study of Poor Women in the Kembar Kelor Village (Feminisasi Kemiskinan Studi Kualitatif pada Perempuan Miskin di Desa Kembar Kelor). Habitus: Jurnal Pendidikan, Sosiologi, dan Antropologi. 2017; 1(1): 1-5.

14. Azwar W, Muliono, Permatasari Y. A Study of the Beggar of Women in the Minangkabau Matrilineal Society in West Sumatera (Feminisasi Kemiskinan: Studi tentang Pengemis Perempuan pada Masyarakat Matrilineal Minangkabau di Sumatera Barat). Jurnal Studi Gender dan Islam. 2018; 17(2): 71-88.

15. Puspanegara I, Ronoatmodjo S. Factors Related to the Quality of Life Of the Elderly in Cipasung Village, Kuningan Regency In 2017 (Faktor-faktor yang berhubungan dengan kualitas hidup lansia di desa cipasung kabupaten kuningan tahun 2017). Jurnal Kesehatan Reproduksi. 2017; 9(1): 96-78.

16. Kusuma H. Relationship between Depression and Family Support with the Quality of Life of HIV / AIDS Patients undergoing Treatment at Cipto Mangun Kusuma Hospital in Jakarta (Hubungan antara Depresi dan Dukungan Keluarga dengan Kualitas Hidup Pasien HIV/AIDS yang menjalani Perawatan di RSUPN 
Cipto Mangun Kusuma Jakarta) [Internet]. Kusuma H. 2011 [cited 2019 Nov 5]. Available from: http://lib.ui.ac.id/file?file=digital/2028 2772-T-Henni\%20Kusuma.pdf.

17. Yacoub Y. The Effect of the Unjob Rate on the Regency/City Poverty Rate in West Kalimantan Province (Pengaruh Tingkat Pengangguran terhadap Tingkat Kemiskinan Kabupaten/Kota di Provinsi Kalimantan Barat). Jurnal Eksos. 2012; 8(3): 176-185.

18. Nurwati N. Poverty: Measurement Model, Problems and Alternative Policies (Kemiskinan: Model Pengukuran, Permasalahan dan Alternatif Kebijakan). Jurnal Kependudukan Padjajran. 2008; 10(1): 1-11.

19. Nangan M, Fitrinika E, Rahayuningsih D, Dinayati E, Aulia FM, Rismalasari M, Hafid M, Wahyu R, Putra RR, Kartika V, Widaryatmo. Analysis of High Poverty Areas (Analisis Wilayah dengan Kemiskinan Tinggi). Kadeputian Bidang Kependudukan dan Ketenagakerjaan Kementerian PPN/Bappenas: Jakarta; 2018. 